\title{
EP Regimen
}

National Cancer Institute

\section{Source}

National Cancer Institute. EP Regimen. NCI Thesaurus. Code C63382.

A regimen consisting of etoposide and cisplatin that can be used in the treatment of nonsmall cell lung cancer (NSCLC), small cell lung cancer (SCLC) and testicular cancer. 